\title{
Emotionally Competent Behaviors and Nurse Bullying: Is There a Direct Link?
}

\author{
Michelle Doas \\ Chatham University, Pittsburgh, USA \\ Email: mdoas@chatham.edu
}

Received 15 December 2014; accepted 9 January 2015; published 15 January 2015

Copyright (C) 2015 by author and Scientific Research Publishing Inc.

This work is licensed under the Creative Commons Attribution International License (CC BY). http://creativecommons.org/licenses/by/4.0/

\section{(c) (i) Open Access}

\section{Abstract}

An abundance of literature spanning many years depicts the devastating effects of nurse bullying within the profession. The evidence suggests that bullying in general is a deliberate act aimed at another person. Conceptualizing nurse bullying appears to be a key ingredient in creating both awareness and preventative strategies. Emotional competence includes a set of behaviors which are unique to each individual. These behaviors according to Goldman (1995) include, but are not limited to emotional self-assessment, accurate self-assurance, self-confidence, emotional selfcontrol, and empathy. The majority of researchers agree that emotionally competent behaviors are impacted by both positive and negative interactions and experiences. Thus, it is hypothesized that emotionally competent behaviors are continually cultivated throughout one's life based upon lived experiences. This article assesses direct relationships between implementation of emotionally competent behaviors as a means of combatting nurse bullying within the profession. Creating awareness of these two areas can be initial steps in cultivating the needed tools and supportive interventions to assist nurses from novice to expert to professionally mentor and role model for generations to come.

\section{Keywords}

Nurse Bullying, Emotional Competence

\section{The Evidence on Nurse Bullying}

An abundance of literature spanning many years depicts the devastating effects of nurse bullying within the profession. Studies show that $60 \%$ of new nurses left their first job within six months due to nurse bullying [1]. Additionally, more than $50 \%$ of nurses surveyed by the ANA cited experiences of nurse bullying which included threatening or verbally abusive language within the workplace. 
The evidence suggests that bullying in general is a deliberate act specifically aimed at another person. Workplace bullying has been described as a gradual, yet intense set of behaviors that may be aimed at an individual and have harmful outcomes [2]. These outcomes include: experiencing physical symptoms and illnesses, decreased workplace productivity, lower self-confidence, lower self-esteem, social isolation, and most extreme thoughts or acts of self-harm.

Conceptualizing nurse bullying appears to be a key ingredient in creating both awareness and preventative strategies. Conceptualizing bullying is difficult due to the vast array of associated definitions. A concrete example describes bullying as "generalized workplace abuse" [3] that is persistent, non-sexual, without physical violence, may involve a power struggle (peer to peer, peer to leader, leader to peer), escalate from minor to severe behaviors, and result in negative outcomes for the nurse being bullied [4] [5]. Based upon research findings, the most common nurse bullying behaviors are illustrated in Table 1.

Based upon the above behaviors, what strategies can be implemented to assist in changing controllable behaviors while utilizing emotionally competent interventions?

Prior to exploring this issue, an overview of emotional competence will be addressed. Emotional competence is a set of behaviors which are unique to each individual. This uniqueness is closely aligned with an individual's life experiences in combination with innate emotional and personality traits. The majority of researchers agree that emotionally competent behaviors are impacted by both positive and negative interactions and experiences. Additionally, it is hypothesized that emotionally competent behaviors are continually cultivated throughout one's life based upon interactions and experiences. For knowing and effectively managing one's behaviors, the following emotionally competent behaviors are deemed most important when addressing ways to combat nurse bullying. These emotionally competent behaviors as identified by Goldman (1995) include emotional selfassessment, accurate self-assurance, self-confidence, emotional self-control, and empathy. According to Goldman, one must be self-aware and in tune with personal emotions in order to effectively interact as well as hold leadership positions. Leadership positions can include but are not limited to roles including, charge nurse, preceptor for new employees, nurse manager or director. Without these emotionally competent attributes, one may not be able to clearly demonstrate therapeutic interactions and role-modeling. Likewise, one must be self-aware of displayed behaviors in order to effectively practice emotional self-control. Emotional self-control is paramount in order to effectively interact with others, build rapport, and manage conflict on any level [12] [13].

Table 1. Bullying behaviors overt covert.

\begin{tabular}{|c|c|c|}
\hline Hostility & Non-verbal gestures including facial gestures & Invasion of personal space \\
\hline Tone of voice & Social isolation & Not speaking or speaking with aggressive tone \\
\hline Diminishing the power of bullying & Calling the nurse names & $\begin{array}{l}\text { Placing blame on the nurse and/or } \\
\text { referring nurse to workplace counselors }\end{array}$ \\
\hline Harassment & $\begin{array}{l}\text { Demeaning, treating "different" than the } \\
\text { majority of other nurses }\end{array}$ & Excessively critical \\
\hline Continual reminder of mistakes/errors & Intolerant & Impatient \\
\hline Intimidation & Making false accusations & Yelling, shouting, using profanity \\
\hline Gossip & $\begin{array}{l}\text { Rumors aimed at turning others against } \\
\text { the individual }\end{array}$ & Public humiliation \\
\hline Condescending & Spreading lies, being deceptive & Vindictive \\
\hline Punishing & Hinting the nurse should transfer or quit & Continual public verbal attacks \\
\hline $\begin{array}{l}\text { Excluding the nurse from } \\
\text { unit based/work based activities }\end{array}$ & $\begin{array}{l}\text { Withholding pertinent information } \\
\text { from the nurse }\end{array}$ & $\begin{array}{l}\text { Excluding from professional/social } \\
\text { networking opportunities that apply to work }\end{array}$ \\
\hline $\begin{array}{l}\text { Ignoring/undervaluing/belittling } \\
\text { the nurse's work }\end{array}$ & $\begin{array}{l}\text { Defaming and/or falsely attacking the } \\
\text { nurse's skill level and/or reputation }\end{array}$ & Excessive teasing which can lead to cruelty \\
\hline Questioning the nurse's competency & Excessive sarcasm & $\begin{array}{l}\text { Public humiliation which could include } \\
\text { destruction of personal property }\end{array}$ \\
\hline
\end{tabular}

[4] [6]-[11]. 
The effects of nurse bullying can be harmful, career shaping and even career ending for some recipients of bullying. The following case study will illustrate the power of nurse bullying and the benefit of displaying emotionally competent behaviors.

\section{Case Study}

A brand new RN, Mary recently passed NCLEX and started a job on a busy inner city medical-surgical unit. Mary was 20 years old and overly eager to begin her nursing career. Most of the nurses on the unit were veteran staff and previously worked together at another hospital. The nurses were reunited through a recent hospital merger. Mary was the only new hire on the unit in two years. She entered her job with intense enthusiasm and passion to do well. Mary's preceptor was selected randomly since none of the nurses had a desire to precept new nurses. In fact, the nurses voiced feelings of viewing the preceptor role as burdensome and extra work without extra pay. As a result, Mary's preceptor ship was anything but positive. She felt like she was set free from the beginning and was verbally put down when asking about basic nursing procedures. For example, one of her patients needed an NG tube inserted. Mary asked her preceptor to observe her inserting the tube. The preceptor rolled her eyes in disgust and verbalized in front of several other staff members that she should know how to do this basic skill. Throughout the weeks, Mary was singled out when asking for support including the verification of skills which were part of the orientation check list. Singling out behaviors included gossiping and spreading rumors of incompetence, placing notes around the unit depicting "how to do specific skills", and assigning Mary to go to lunch alone. As a result, Mary started isolating herself from coworkers, questioned her abilities, and quit the job after three months. Mary decided to quit since she felt unsupported, excessively criticized, and isolated. Table 2 illustrates the five emotionally competent behavior in relationship to Mary, preceptor, and staff.

\section{Implications for Practice}

Creating awareness on the power of nurse bullying and the benefits of assessing and implementing emotionally competent behaviors is essential in creating a culture of change, acceptance and professionalism within today's nursing environment. Both awareness and reflection can assist in turning the Mary experiences into positive and meaningful professional encounters. Table 3 displays integration of each of the five emotionally competent behaviors into Mary's case study.

Table 2. Emotionally competent behaviors.

\begin{tabular}{|c|c|c|c|c|}
\hline $\begin{array}{l}\text { Emotional } \\
\text { self-assessment }\end{array}$ & $\begin{array}{c}\text { Accurate } \\
\text { self-assurance }\end{array}$ & Self-confidence & Emotional self-control & Empathy \\
\hline $\begin{array}{c}\text { *2 Lacking by } \\
\text { preceptor/staff } \\
\text { as evidenced by } \\
\text { bullying behaviors. }\end{array}$ & $\begin{array}{l}{ }^{*} \text { Preceptor/staff } \\
\text { appeared self-assured } \\
\text { in professional role } \\
\text { but behaviors } \\
\text { hindered Mary’s } \\
\text { ability to display } \\
\text { self-assurance. }\end{array}$ & $\begin{array}{l}\text { *Preceptor/staff appeared } \\
\text { to be self-confident in } \\
\text { clinical skills and role but } \\
\text { behaviors hindered Mary’s } \\
\text { ability to build } \\
\text { self-confidence } \\
\text { as a new nurse. }\end{array}$ & $\begin{array}{l}\text { *Lacking by preceptor/staff as evidenced by } \\
\text { bullying behaviors including gossiping, } \\
\text { placing notes around unit, and attempts at } \\
\text { isolating Mary during break times. } \\
\text { It appears as though Mary demonstrated } \\
\text { emotional self-control by removing herself } \\
\text { from the negative environment even though } \\
\text { the outcome (quitting job) was not desirable. }\end{array}$ & $\begin{array}{c}{ }^{*} \text { Lacking by } \\
\text { preceptor/staff as } \\
\text { evidenced by } \\
\text { bullying behaviors. }\end{array}$ \\
\hline
\end{tabular}

Table 3. Integration of emotionally competent behaviors.

\begin{tabular}{|c|c|c|c|c|}
\hline Emotional self-assessment & Accurate self-assurance & Self-confidence & Emotional self-control & Empathy \\
\hline Preceptor/staff: & Preceptor/staff: & Preceptor/staff: & Preceptor/staff: & Preceptor/staff: \\
\hline $\begin{array}{l}\text { Understand why they are } \\
\text { feeling emotions related to } \\
\text { not wanting to precept new } \\
\text { nurses, realize the vital link } \\
\text { associated with these } \\
\text { feelings and interpersonal } \\
\text { interactions, recognize how } \\
\text { feelings affect behaviors and } \\
\text { interpersonal interactions. }\end{array}$ & $\begin{array}{l}\text { Being aware of individual } \\
\text { strengths which are } \\
\text { important to share with new } \\
\text { nurses, being open-minded } \\
\text { in relationship to becoming } \\
\text { a preceptor, professional } \\
\text { role model, and overall } \\
\text { mentor. }\end{array}$ & $\begin{array}{l}\text { Being aware of } \\
\text { personal and } \\
\text { professional strengths, } \\
\text { realizing the value of } \\
\text { sharing professional } \\
\text { experiences and skills } \\
\text { with new nurses. }\end{array}$ & $\begin{array}{l}\text { Becoming aware of the } \\
\text { negative effects of } \\
\text { displaying negative } \\
\text { behaviors and negative } \\
\text { emotions, realizing the } \\
\text { value of maintaining } \\
\text { self-control and } \\
\text { professional behaviors } \\
\text { through professional } \\
\text { role modeling. }\end{array}$ & $\begin{array}{l}\text { Never forgetting what it felt } \\
\text { to be a new nurse with a } \\
\text { new job on a new unit, } \\
\text { sensing the value of } \\
\text { displaying sensitivity and } \\
\text { caring behaviors, realizing } \\
\text { the power of perception. }\end{array}$ \\
\hline
\end{tabular}


Both bullying behaviors and emotionally competent behaviors may be learned, mimicked, and developed. Emotional self-assessment, accurate self-assurance, self-confidence, emotional self-control and empathy are essential in combatting nurse bullying. Creating awareness of both emotional competence and bullying can be an initial step in cultivating needed tools and support to assist nurses, to professionally role model in the midst of ever changing health care environments.

\section{References}

[1] Townsend, T. (2012) Break the Bullying Cycle. American Nurse Today.

[2] Hutchinson, M. (2005) Like Wolves in a Pack: Stories of Predatory Alliance of Bullies in Nursing. Health Care Management Review, 30, 331-336. http://dx.doi.org/10.1097/00004010-200510000-00007

[3] Namie, G. and Namie, R. (2000) The Bully at Work. Sourcebooks, Inc., Naperville.

[4] Keashly, L. and Jagatic, K. (2003) By Any Other Name: American Perspectives on Workplace Bullying. In: Einarsen, E., Hoel, H., Zapf, D. and Cooper, C., Eds., Bullying and Emotional Abuse in the Workplace: International Perspectives in Research and Practice, Taylor \& Francis, New York, 31-36.

[5] Rayner, C. and Hoel, H. (1997) A Summary Review of Literature Relating to Workplace Bullying. Journal of Community \& Applied Social Psychology, 7, 181-191. http://dx.doi.org/10.1002/(SICI)1099-1298(199706)7:3<181::AID-CASP416>3.0.CO;2-Y

[6] Cowie, H., Naylor, P., Rivers, L., Smith, P.K. and Pereira, B. (2002) Measuring Workplace Bullying. Aggression and Violent Behavior, 7, 33-51. http://dx.doi.org/10.1016/S1359-1789(00)00034-3

[7] Farrell, G.A. (1999) Aggression in Clinical Settings: Nurses’ Views-A Follow up Study. Journal of Advanced Nursing, 29, 532-541. http://dx.doi.org/10.1046/j.1365-2648.1999.00920.x

[8] Farrell, L.U. (2002) Workplace Bullying's High Cost: 180 Million Dollars Lost in Time, Productivity. Orlando Business Journal. http://orlando.bizjournals.com/orlando/stories/2002/03/18/focus1.html

[9] Glendinning, P.M. (2001) Workplace Bullying: Curing the Cancer of the American Workplace. Public Personnel Management, 30, 260-286.

[10] Hoel, H., Faragher, B. and Cooper, C. (2004) Bullying Is Detrimental to Health, but All Bullying Behaviors Are Not Necessarily Equally Damaging. British Journal of Guidance \& Counselling, 32, 367-387. http://dx.doi.org/10.1080/03069880410001723594

[11] Jackson, D., Clair, J. and Mannix, J. (2002) Who Would Want to Be a Nurse? Violence in the Workplace-A Factor in Recruitment and Retention. Journal of Nursing Management, 10, 13-20. http://dx.doi.org/10.1046/j.0966-0429.2001.00262.x

[12] Goleman, D., Boyatzis, R. and McKee, A. (2002) Primal Leadership: Realizing the Power of Emotional Intelligence. Harvard Business School Press, Boston.

[13] Hay Group (2004) Emotional Intelligence Services. http://www.haygroup.com/leadershipandtalentondemand/your-challenges/emotional-intelligence/index.aspx 
Scientific Research Publishing (SCIRP) is one of the largest Open Access journal publishers. It is currently publishing more than 200 open access, online, peer-reviewed journals covering a wide range of academic disciplines. SCIRP serves the worldwide academic communities and contributes to the progress and application of science with its publication.

Other selected journals from SCIRP are listed as below. Submit your manuscript to us via either submit@scirp.org or Online Submission Portal.
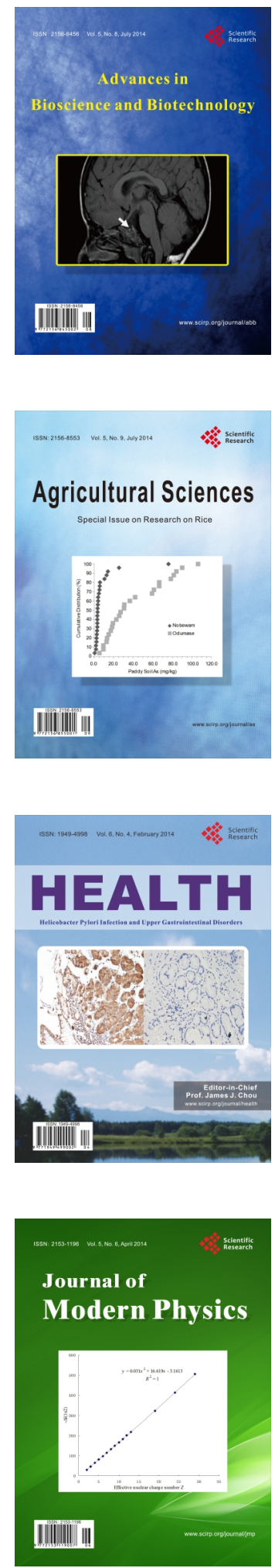
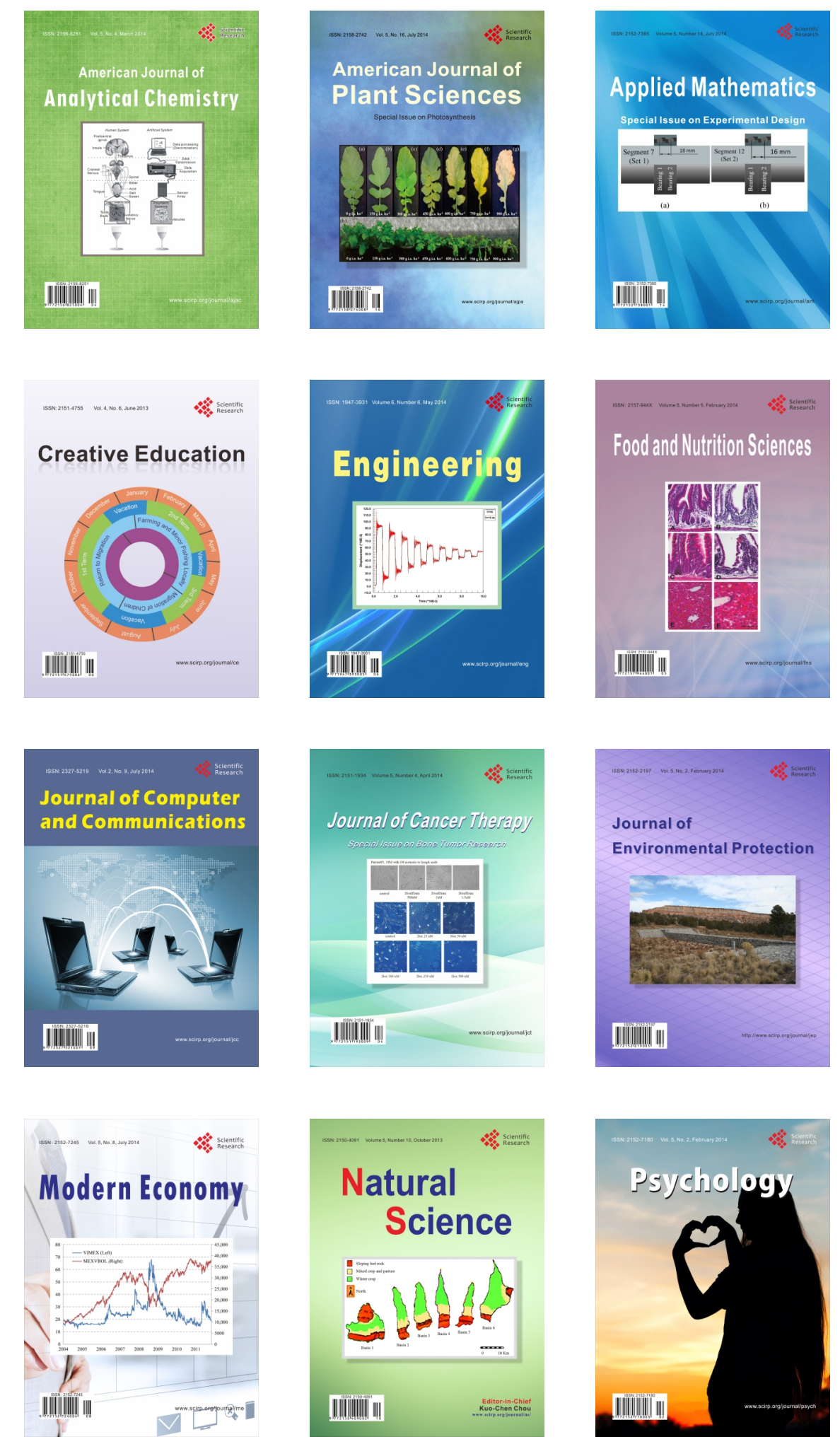